\title{
Nurse Perceived of Caring Leadership: A Qualitative Descriptive Study
}

\author{
Ni Made Nopita Wati ${ }^{1 *}$ (D) R. Tri Rahyuning Lestari ${ }^{2}$, Gita Ayuningtyas ${ }^{2}$, Ni Bodro Ardi $^{2}$, I Gede Juanamasta ${ }^{1}$ (D) \\ ${ }^{1}$ Department of Nursing, STIKes Wira Medika Bali, Denpasar, Indonesia; ${ }^{2}$ Department of Nursing, STIKes Widya Dharma \\ Husada Tanggerang, Banten 15417, Indonesia
}

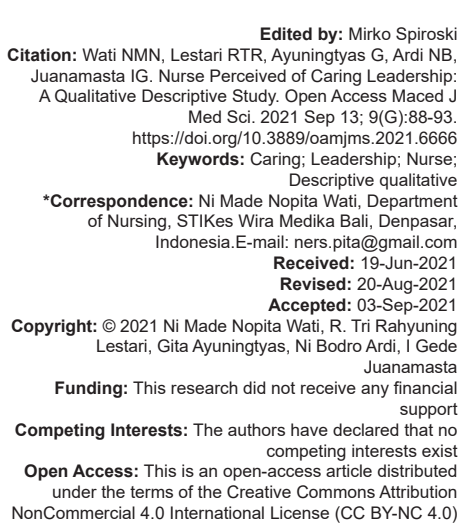

Edited by: Mirko Spiroski Citation: Wati NMN, Lestari RTR, Ayuningtyas G, Ardi NB, Juanamasta IG. Nurse Perceived of Caring Leadership: A Qualitative Descriptive Study. Open Access Maced $J$ Med Sci. 2021 Sep 13; 9(G):88-93 ps://doi.org/10.3889/oamjms.2021.6666 Keywords: Caring; Leadership; Nurse: Descriptive qualitative
*Correspondence: Ni Made Nopita Wati, Department of Nursing, STIKes Wira Medika Bali, Denpasar,
. Indonesia.E-mail: ners.pita@gmail.com Received: 19-Jun-202 Accepted: 03-Sep-202 Copyright: $\odot 2021$ Ni Made Nopita Wati, R. Tri Rahyunin Lestari, Gita Ayuningtyas, Ni Bodro Ardi, I Gede Funding: This research did not receive any financial Competing Interests: The authors have declared support Competing Interests: The authors have declared that $n$ Open Access: This is an open-access article distributed under the terms of the Creative Commons Attribution NonCommercial 4.0 International License (CC BY-NC 4.0)

\section{Abstract}

BACKGROUND: The leader's attitude or behavior to staff or subordinates greatly determined a conducive working atmosphere in a hospital. Decrease in performance and job dissatisfaction will impact work productivity, attendance (absenteeism), the quality of services provided, and the exit of the workforce itself (turn-over). This is why the importance of a harmonious relationship between a leader and his staff or subordinates.

AIM: This study aims to determine nurses' views regarding caring leadership of the head of the room.

METHODS: The research method used in this study is descriptive qualitative with a face-to-face interview. Fifteen registered nurses were involved in this study that interacts directly to the patient and nurse manager. The data were analyzed by content analysis.

RESULTS: Nurse perceived caring leadership, including giving positive feelings, listening, encouraging, influencing experience, proactive, and struggling for the subordinates.

CONCLUSION: A deep understanding of caring leadership could bring the curricula with the new course of caring leadership. The student can learn and practice from the early time. It would bring a caring attitude as a part of their own life.

\section{Introduction}

As one of the health-care providers in hospitals, nurses play a critical role in accomplishing health development goals. The success of health services depends on the participation of nurses in providing quality care for patients [1], [2]. This is due to the presence of nurses on duty $24 \mathrm{~h}$ to serve patients, as well as the number of nurses who dominate health workers in hospitals, which ranges from 40 to $60 \%$, thus hospitals need to manage human resources (HR), especially nurses appropriately [3]. It takes the existence of a leader who is able to manage HR in accordance with the changes and existing demands [4], [5].

A leader uses his authority and leadership to direct others and is responsible for that person's work in achieving a goal [6]. Leaders have a responsibility both physically and spiritually for the success of the work activities of those they lead, so being a leader is not easy, and not everyone has the same in carrying out their leadership (Milkhatum, 2016). Leaders who are aware of their strengths and weaknesses and know how their behavior will affect their staff [7]. The research results conducted by Laschinger stated that emotional exhaustion, which is considered a core component of burnout, is influenced by leadership. Similar research results were also expressed by Pinchover, AttarSchwartz [8], where the closer the relationship between the leader and the staff and the higher the level of trust the leader has on the staff, the lower the burnout level. Leaders who have the ability to empower their staff well will indirectly reduce the level of emotional exhaustion of their staff [9].

Leadership style is a significant predictor to increase job satisfaction. The higher the perception of the leadership style, the higher the job satisfaction of employees [10]. The study conducted by Ayalew and Kibwana [11] showed a significant relationship between motivation and job satisfaction of nurses to increase the motivation of nurses at work further. Nurse's motivation can pursue by giving awards to nurses from their leaders or superiors in achieving job satisfaction. In addition, a person's leadership style has a great influence on climate and group work outcomes [12]. One leadership style is caring leadership. Caring behavior of leaders to implementers or staff is called caring leadership.

Based on the importance of the leadership above, this study purposed to explore how nurses perceived of caring leadership. The caring leadership style would give a positive impact on the nurse staff, 
and stimulate nurse manager innovation and creativity for implementing it.

\section{Methods}

\section{Research design}

The study used a qualitative method with a descriptive approach [13]. The study wanted to discover and understand the understanding of caring leadership from the clinical nurse [14].

\section{Research participants}

The participants of the research included 15 registered nurses (RNs) at Dharma Yadnya General Hospital, Denpasar, Bali. In Indonesia, an RN refers to a nurse who has a certificate of competence that a letter of acknowledgment of the ability of a nurse. The certificate can acquire after passing the competency test by the nursing council. A renewal review is required every 5 years.

For convenience, the authors talked with the nurse manager about the purpose of the research. After obtaining the permission, the authors ask the nursing staff to join the research. The author explained the objective of this study and the plan of the interview. Three of nurses gave a good response and made an appointment for the interview. The author described the details of the study and gave informed concern before starting the interview. RNs who had consented to participate in the research signed the informed concern. Forward, we used the snowball sampling technique that we asked the participants to introduce a new participant candidate and obtained their consent using a snowball sampling technique.

\section{Data collection}

The data collection method used face-toface interviews to understand the RN's perceptions of caring leadership [15]. The interview was conducted in Indonesia Language. Almost all of the interviews were conducted in the nurse's ward meeting room at the hospital in the afternoon after the participants finish their working shift. The first author interviewed the interviewees one by one for approximately an hour, and the second and third checked the data saturation. The study used a semi-structured interview data collection method which was carried out using an interview guide. Interview guidelines included the demographic of participants and the main questions related to the experience which was required to gain knowledge. Details of the interview were we asked participants to explain what their notion of caring leadership, what kind of the leader characthers with caring leadership, and things that the participants realized through their experience. Data collection was conducted from the end of June until the end of November 2018.

\section{Data analysis}

This study used qualitative content analysis [16]. This analysis was chosen to summarize the content of information based on verbal and visual data [17]. The data analysis process of acquiring practical knowledge started since nurses had been planning to obtain the qualification, and what kind of process led them to acquire practical knowledge. The recorded conversations were transcribed word by word, then the data from each participant were collected. The relevant data were divided into several chunks of code [13]. Then, each code was compared with the others. Those that shared the same detail were consolidated and coded once again. Next, we drew a relationship diagram between each participant based on the correlation between codes.

After that, each participant's code was continuously compared and examined to derive subcategories. The relationships between sub-categories were interpreted and summarized into categories again, and the correlation was established as the process [15]. All of those processes are recorded in Excel files to ensure confirmability and dependability. Participants descriptions were described in the result to show their background for enhancing the transferability of this study, which are shown in Table 1 [18]. Furthermore, to maintain the credibility of the research, we sent the summary and diagram of the process to three research participants and performed member checking [13]. Throughout the research, we held discussions with collaborators specializing in qualitative descriptive research and nursing leadership to improve its accuracy [13], [19].

\section{Ethical consideration}

This research was conducted after receiving approval from the Research Ethics Committee of the Bali Institute of Technology and Health No. 03.0379/ KEPITEKES-BALI/IV/2018. The research purpose, objective, and methods were explained in writing and verbally to participants, and upon their understanding, the participants signed the consent form and agreed to participate in the research. We explained to the participant that participation was voluntary, and the participants were allowed to withdraw anytime, even after consenting. The participants and institution names were not identified to comply with privacy protection. The data obtained from interviews would not be used for any purpose other than this research and would not be shared with anyone other than research collaborators. 


\section{Results}

Based on Table 1, it can be seen that most of the respondents are female 9 nurses (56.3\%), early adulthood (26-35 years) 7 nurses (43,7\%), 13 nurses $(81.2 \%)$ three-years diploma education, 9 nurses $(56.3 \%)$ have experience more than 3 years, and 6 nurses $(37.6 \%)$ work inpatient ward.

Table 1: Demographics of respondents

\begin{tabular}{lll}
\hline Demographics & $\mathrm{n}$ & $\%$ \\
\hline Sex & & \\
$\quad$ Male & 7 & 43.7 \\
$\quad$ Female & 9 & 56.3 \\
Age & & \\
$\quad$ Late adolescence (17-25 years) & 5 & 31.2 \\
$\quad$ Early adulthood (26-35 years) & 7 & 43.7 \\
$\quad$ Late adulthood (36-45 years) & 2 & 12.5 \\
$\quad$ Early old age (46-55 years) & 2 & 12.5 \\
Education & & \\
$3^{\text {rd diploma degree }}$ & 13 & 81.2 \\
$4^{\text {th }}$ diploma degree & 2 & 12.5 \\
Bachelor degree & 1 & 6.3 \\
Working experience & & \\
$\quad<3$ years & 7 & 43.7 \\
$>3$ years & 9 & 56.3 \\
Department & & \\
$\quad$ Inpatient ward & 6 & 37.6 \\
Intensive care unit & 2 & 12.5 \\
Emergency unit & 3 & 18.7 \\
Operating room unit & 2 & 12.5 \\
Hemodialysis unit & 3 & 18.7 \\
Total & 16 & 100 \\
\hline
\end{tabular}

There are four themes in this study that describe the various perceptions of nurses about implementing caring leadership. These themes are: (1) Taking care of giving positive feeling, (2) listening and encouraging the staff, (3) experience and influence, and (4) being proactive and struggling for the subordinates. The themes generated in this study are discussed separately to reveal the meaning or significance of the nurses' perceptions of caring leadership.

\section{Taking care for giving positive feelings}

Participants in this study described the notion of caring leadership as a concern of positive feeling to staff or subordinates. The positive feelings would give a positive spirit to the nursing staff, and they would give a positive atmosphere to the patient. As expressed by the four participants in this study:

"concern for something." (P11)

"Caring is the essence of nursing. Caring can help clients promote positive changes in psychological, spiritual and social terms." (P2)

client”. (P3)

"... taking care of the client, taking action to the

". how to deliver the adequate nursing care, we consistently make an effort to provide excellent service to our clients." (P14)

\section{Listening and encouraging the staff}

The participant expressed a leader with caring leadership has to listen and encourage the nursing staff. Nurse leader could give their attention to the staff problem in the working place, motivate them, and empathize. The participants said as below:

"Leadership based on concern for subordinates." (P8)

"... a leader who is able to listen, and pay attention to staff complaints and needs even when the leader is busy.". (P1)

"... a person who is concerned about our working conditions". (P4)

"... a way to motivate or encourage clients in the nursing care process so that professional nursing care can be realized...". (P13)

“... provide motivation or empathy to clients in the healing process". (P5)

“... be a bridge between doctors and patients in the patient's recovery process by always providing encouragement or motivation so that they can carry out treatment to a complete extent". (P5)

\section{Experience and influence}

The ideal leader with a caring leadership style should have good work experience and education. Besides, the leader could give influence to their staff that would make the staff trust and follows the leader. Moreover, a role model is a must as a leader. This was revealed as follows:

"Ideally from an educational perspective, you have a bachelor's status, then the second has the power to lead a unit, then you can also provide a maximum service to patients.". (P4)

"Every team/organization should have a leader who values his subordinates and works with them to fulfill tasks.,". (P6)

"... able to listen, and pay attention to staff complaints and needs even when the leader is busy". (P15)

"... if there is a problem with the patient, the leader provides a solution... there is no need to talk too much, the leader knows there is a problem". (P9)

“... very helpful in realizing Nursing Care by providing motivation or encouragement in the healing process". (P7)

"...a leader who sets an example, we must be able to set an example as a leader, give a decision...". (P5)

\section{Proactive and struggling for his subordinates}

The leader must be proactive to his subordinates and fight for his subordinates and patients. This can be seen in the interview: 
"Appreciate leaders who care and can embrace their subordinates rather than leaders who can only order without discussing." (P1)

"...In order to play a significant role in decision making, they must take an engaged and aggressive approach." (P12)

"must work from the leader." (P3)

". we provide training, workshops to our friends to support it, well. what are the levels of education if we support D3." (P7)

\section{Discussions}

The participant explained the caring leadership style is a leadership style that gives positive feelings, listening, encouraging, influencing, experience, proactive, and struggling for the subordinates. Those character of caring leadership is slightly close with Swanson's caring theory which provides a good starting point for understanding the habits and processes characteristic of service. Swanson's caring theory explains the caring process which consists of how nurses understand meaningful events in a person's life, are emotionally present, do things to others as well as do things for themselves, provide information, and facilitate one's path in life transitions and put one's belief in life [20]. Thus, the leader could try to understand their workplace situation, and then emotionally encourage the staff to overcome the working situation.

Caring, according to Swanson, is an effort to maintain relationships with others based on responsibility, commitment, a sense of belonging, and respect for others. Leadership or leadership is the process of influencing or setting an example by the leader to his followers in an effort to achieve organizational goals [21]. Leadership in nursing is the ability and skill of a nurse leader in influencing other nurses under their supervision to carry out their duties and responsibilities in providing services. The behavior of the leader has a very strong influence on the performance of the executor, if positive behavior is increased in the implementation of the activity, the performance of the executor will greatly increase. Caring leadership is a model that answers the core of the required leadership. Caring leadership leads using human values, such as leading with compassion and equality, leading by fostering hope, actively fostering innovation with insight, wisdom, always reflecting, and leading by creating space for staff to be creative, respectful, and caring [21]

Based on the results of the interviews, one participant stated that educational experience is ideal in applying a caring leadership style and four other participants mentioned soft skills as an ideal part of caring leadership. Leadership is the art of influencing and directing people by means of obedience, trust, respect, and passionate cooperation to achieve common goals [22]. An organization's efforts to improve the quality of its performance require leadership that always motivates other members of the organization to always improve the quality of their work. It can be concluded that leadership is a person's ability to influence, move, encourage, control other people or their subordinates to do some work on their consciousness, and contribute to achieving a goal. Based on the meaning of leadership, a leader is really expected by his subordinates to have a better experience. This experience is obtained based on direct knowledge and practice so that this makes a leader able to influence his subordinates.

Soft skills are an attitude or part of an emotional-based ability. Four participants mentioned soft skills related to giving positive feelings, motivation, listening to complaints, and paying attention to staff needs. This is in accordance with the character of caring, namely a sense of belonging and respect for others. Caring leadership leads using human values such as leading with compassion and equality, leading by fostering hope, actively fostering innovation with insight, wisdom, always reflecting, and leading by creating space for staff to be creative, respectful, and caring [21], [23].

All participants were able to explain the application of caring leadership well and how the participants as implementing nurses were able to support the application of caring leadership. Overall, in the application of caring leadership, the leader must be active and proactive to subordinates and fight for their subordinates and patients.

Wati [21] stated that caring leadership has five phases, namely knowing, being with, doing for, enabling, and maintaining belief. The knowing phase is where a leader can find out or identify the problems that exist in his work. The leader must seek the truth or facts based on evidence so that the cause of the problem can be identified. In the next phase, a leader must be able to cooperate with his subordinates and be able to establish harmonious communication with his subordinates. The leader creates good communication with his subordinates so that subordinates are able to receive input or suggestions in overcoming these problems. The doing for phase is that a leader must be able to do something for his subordinates, not for himself, and provide comfort for his subordinates. In this phase, the leader provides comfort to subordinates, protects subordinates, and maintains their dignity, so that subordinates feel comfortable and a relationship of mutual respect is created. The enabling phase is that a leader must be able to provide information and explain something that his subordinates do not 
understand and support positive activities carried out by his subordinates. Finally, a leader must be able to maintain and convince his subordinates, namely the maintaining belief phase.

The study has the limitation from the methodology, perhaps there is a bias if we ask from the nurse manager perspective as a leader or from the hospital upper management based on their experience as a leader. Further study needs to test these attributes of caring leadership, it can represent or not. The study could not generalize because the workplace situation and leader character might influence their perception of caring leadership.

\section{Conclusion}

Nurse perceived caring leadership that the leader should give positive feelings, listening, encouraging, influencing, experience, proactive, and struggling for the subordinates. In addition, caring leadership is a new leadership style for nursing. It could help practical nurses, specifically nurse managers, to manage their ward and the staff. This would increase the staff performance personally and ward performance as a group. Besides, it is valuable for nursing knowledge that caring can be used as a leadership style.

Nursing education and research should explore it more. A deep understanding of caring leadership could bring the curricula with the new course of caring leadership. The student can learn and practice from the early time. It would bring a caring attitude as a part of their own lifes.

\section{References}

1. Arini T, Juanamasta IG. The role of hospital management to enhance nursing job satisfaction. Indones Nurs J Educ Clinic. 2020;5(1):82-6. https://doi.org/10.24990/injec.v5i1.295

2. Juanamasta IG. Pemodelan Konsep Diri Profesional Perawat Terhadap Produktifitas Kerja Perawat Pelaksana di Ruang Rawat Inap. Surabaya: Universitas Airlangga; 2018. https://doi. org/10.30996/jmm17.v1i01.311

3. Nuryani SA, Wati NM, Juanamasta IG. Nursing grand rounds (NGRS) regularly to encourage continuing professional development (CPD) achievement of nurses. Pak J Med Health Sci. 2020;14(4):3.

4. Rodessa V, Kurniadi A, Bandur A. The impact of preceptorship program on turnover intention of fresh graduate nurses in hospital. Babali Nurs Res. 2020;1(3):131-48. https://doi. org/10.37363/bnr.2020.1334

5. Juanamasta IG, Wati NM, Widana AA. Covid-19: A balinese viewpoint. Belitung Nurs J. 2020;6(4):143-4. https://doi. org/10.33546/bnj. 1133
6. Mohiuddin ZA. Influence of leadership style on employees performance: Evidence from literatures. J Market Manage. 2017;8(1):18-30.

PMid:123730302

7. Laschinger HK, Wong CA, Grau AL. Authentic leadership, empowerment and burnout: A comparison in new graduates and experienced nurses. J Nurs Manage. 2013;21(3):541-52. https://doi.org/10.1111/j.1365-2834.2012.01375.x PMid:23405976

8. Pinchover S, Attar-Schwartz S, Matattov-Sekeles H. Director's leadership and burnout among residential child care workers: Possible implications for practice. Scottish J Resident Child Care. 2015;14(2):1-11

9. Dust SB, Resick CJ, Margolis JA, Mawritz MB, Greenbaum RL. Ethical leadership and employee success: Examining the roles of psychological empowerment and emotional exhaustion. Leader Quart. 2018;29(5):570-83. https://doi.org/10.1016/j. leaqua.2018.02.002

10. Dartey-Baah K, Ampofo E. "Carrot and stick" leadership style. Afr J Econ Manage Stud. 2016;7(3):328-45. https://doi.org/10.1108/ ajems-04-2014-0029

11. Ayalew F, Kibwana S, Shawula S, Misganaw E, Abosse Z, van Roosmalen $\mathrm{J}$, et al. Understanding job satisfaction and motivation among nurses in public health facilities of Ethiopia: A cross-sectional study. BMC Nurs. 2019;18(1):46. https://doi. org/10.1186/s12912-019-0373-8 PMid:31636508

12. Alilyyani B, Wong CA, Cummings G. Antecedents, mediators, and outcomes of authentic leadership in healthcare: A systematic review. Int J Nurs Stud. 2018;83:34-64. https://doi.org/10.1016/j. ijnurstu.2018.04.001 PMid:29684833

13. Colorafi KJ, Evans B. Qualitative descriptive methods in health science research. HERD. 2016;9(4):16-25. https://doi. org/10.1177/1937586715614171 PMid:26791375

14. Sandelowski M. What's in a name? Qualitative description revisited. Res Nurs Health. 2010;33(1):77-84. Epub 2009/12/17. https://doi.org/10.1002/nur.20362

PMid:20014004

15. Doyle L, McCabe C, Keogh B, Brady A, McCann M. An overview of the qualitative descriptive design within nursing research. J Res Nurs. 2019;25(5):443-55. https://doi. org/10.1177/1744987119880234 PMid:34394658

16. Yamamoto-Mitani N, Saito $Y$, Takaoka M, Takai $Y$, Igarashi $A$. Nurses' and care workers' perception of care quality in Japanese long-term care wards: A qualitative descriptive study. Glob Qual Nurs Res. 2018;5:1-12. https://doi. org/10.1177/2333393618812189 PMid:30547055

17. Sandelowski M. Whatever happened to qualitative description? Res Nurs Health. 2000;23(4):334-40. https://doi. org/10.1002/1098-240x(200008)23:4<334:aid-nur9>3.0.co;2-g PMid: 10940958

18. Cope DG. Methods and meanings: Credibility and trustworthiness of qualitative research. Oncol Nurs Forum. 2014;41(1):89-91. https://doi.org/10.1188/14.onf.89-91 PMid: 24368242

19. Guba EG. Criteria for assessing the trustworthiness of naturalistic inquiries. ECTJ. 1981;29(2):75. https://doi. org/10.1007/bf02766777

PMid:24368242

20. Schwerin Jl. The timeless caring connection Nurs Admin Quart. 2004;28(4):265-70. https://doi. org/10.1097/00006216-200410000-00007 
PMid:15612401

21. Wati NM, Dwiantoro L, Juanamasta IG. Caring leadership mentoring for charge nurse in inpatient units. Int J Innov Sci Res Technol. 2019;4(7):5. https://doi.org/10.31227/osf.io/a592v

22. Joullié JE, Gould AM, Spillane R, Luc S. The language of power and authority in leadership. Leader Quart. 2020;32(4):101491. https://doi.org/10.1016/j.leaqua.2020.101491

23. Aungsuroch $Y$, Juanamasta IG, Gunawan J. Experiences of patients with coronavirus in the COVID-19 pandemic era in Indonesia. Asian J Public Opin Res. 2020;8(3):16. 